\title{
AN ASSESSMENT OF TREE BANDING TECHNIQUES TO CAPTURE CANKERWORM DEFOLIATORS OF ELM AND ASH TREES IN WINNIPEG, MANITOBA, CANADA
}

\author{
Kerienne R. La France and A. Richard Westwood
}

\begin{abstract}
Fall cankerworm (Alsophila pometaria L.) and spring cankerworm (Paleacrita vernata Peck) are widely distributed across North America. The larvae feed on the leaves of several species of urban street trees, and repeated severe defoliation can cause a reduction in growth and may contribute to tree mortality. This study examined the effectiveness of Tanglefoot ${ }^{\mathrm{TM}}$-covered tree bands and the Bug Barrier Tree Band ${ }^{\mathrm{TM}}$ in preventing the upward movement of female cankerworms on the trunk by comparing capture rates of adult moths. There were no significant differences among tree species in the number of A. pometaria adults caught, while P. vernata showed a preference for elm (Ulmus spp.) over ash (Fraxinus spp.). Up to $25 \%$ of female moths crossed the Bug Barrier Tree Band, and up to $20 \%$ of females crossed the Tanglefootcovered bands in three experiments in 2002 and 2003. There was no significant difference between the two band types in the proportion of females crossing bands. Larval populations were not large enough to determine the effect of the bands on reducing tree defoliation. The Bug Barrier Tree Band was easier to install and remove than the Tanglefoot-covered bands and required considerably less clean-up afterward.
\end{abstract}

Key Words. Alsophila pometaria; defoliation; Paleacrita vernata; tanglefoot bands.

\section{LITERATURE AND BACKGROUND}

The larvae of the fall cankerworm (Alsophila pometaria L.) and the spring cankerworm (Paleacrita vernata Peck) (Lepidoptera: Geometridae) feed on the leaves of many urban deciduous tree species in North America, including American elm (Ulmus americana L.), Siberian elm (U. pumila L. ), basswood (Tilia americana L.), Manitoba maple/boxelder (Acer negundo L.), and ornamental apple trees (Malus spp.) (Martineau 1984; Ives and Wong 1988; Hiratsuka et al. 1995). Alsophila pometaria and P. vernata are widely distributed across North America and range from the eastern Maritime provinces to Alberta in Canada and throughout the eastern United States (Baker 1972; Hiratsuka et al. 1995). Repeated severe defoliation can reduce growth of ornamental and street trees or make trees susceptible to secondary pest problems (Baker 1972; Ives and Wong 1988; Hiratsuka et al. 1995). Several consecutive years of defoliation may contribute to tree mortality (Ives and Wong 1988; Hiratsuka et al. 1995). Larvae also drop from infested trees on silken threads and become a public nuisance when populations are large (Hiratsuka et al. 1995).

Unlike most members of the geometrid family, the adult female moths of both species are wingless, while adult males have fully developed wings (Baker 1972). Alsophila pometaria has one generation per year (Hiratsuka et al. 1995). Larvae hatch in early spring to feed and reach maturity in mid-June. Mature larvae drop from the tree to the ground on silken threads and burrow into the soil to pupate. Adults emerge in late fall, and the female moths climb trees to mate with the males and then lay eggs on twigs and bark in the canopy, where they remain until the following spring (Hiratsuka et al. 1995). Females often lay their eggs on the same tree on which they fed as larvae, as larvae do not travel far before burrowing into the ground, and newly emerged females often crawl to the nearest tree (Schneider 1980).

Paleacrita vernata also has one generation per year (Hiratsuka et al. 1995). The life cycle of $P$. vernata is similar to that of A. pometaria, except that adults emerge in early spring rather than in the fall to mate. Females lay eggs in the canopy, which hatch several weeks later (Hiratsuka et al. 1995). Larvae hatch and begin to feed in the spring, mature and drop from the tree in mid-June, and spend the winter in the soil (Baker 1972; McGuffin 1977).

There are several chemical, biological and mechanical methods of control used by municipalities and homeowners to limit cankerworm defoliation. The City of Winnipeg uses biological insecticides such as Thuricide ${ }^{\circledR} 48 \mathrm{LV}$, which contains Bacillus thuringiensis var. kurstaki (Btk). Thuricide is effective against certain lepidopterous pests including cankerworms (T. Stuart, City of Winnipeg, pers. comm.). Another popular method of cankerworm control for home owners and municipalities in Canada is the use of sticky bands. This method includes a layer of fiberglass pipe insulation wrapped around the trunk of the tree, which is then coated with sticky Tree Tanglefoot ${ }^{\mathrm{TM}}$ (hereafter referred to as "tanglefoot bands") (Tanglefoot Company 2005). The objective is to catch female cankerworms as they crawl up the tree to prevent them from laying eggs. Tanglefoot bands have been in use in Winnipeg, Manitoba, since the early 1970s (M. Barwinsky, City of Winnipeg, pers. comm.). 
Every year, approximately 10,000 to 20,000 tanglefoot bands are installed on street trees in Winnipeg to prevent cankerworm defoliation (M. Barwinsky, City of Winnipeg, pers. comm.). Despite the popularity of tree bands, there are several problems associated with their use: (1) bands can become overcrowded with dead insects, which female cankerworms may use as a "bridge" to cross the barrier and, as more insects are caught, the efficacy of the band may decrease; (2) moisture accumulates beneath the fiberglass insulation and can encourage the growth of fungi on the bark of the tree; and (3) the tanglefoot substance is very messy to apply and requires considerable clean-up (Ascerno and Hahn 2003).

Otvos and Hunt (1986) showed that tanglefoot bands were very effective in the capture of winter moth (Operophtera brumata L.). The life cycle of O. brumata is similar to that of A. pometaria, and females of O. brumata are also wingless. The study compared three types of barriers: (1) a fiberglass barrier around the trunk, (2) a fiberglass barrier sprayed with Raid ${ }^{\circledR}$, and (3) a polyethylene band coated in Tree Tanglefoot. The results of the study found that significantly fewer females passed the tanglefoot barrier in comparison to the other treatments. In addition to being highly effective, Otvos and Hunt (1986) recommended that the Tree Tanglefoot barrier be used as a control for winter moth because it was nontoxic and it eliminated the need for insecticide application.

Thorpe et al. (1993), assessed the efficacy of sticky barrier bands on gypsy moth (Lymantria dispar L.) (Lepidoptera: Lymantriidae) larval density and oak tree defoliation. Adults of both sexes of $L$. dispar have wings, but the females cannot fly (Hiratsuka et al. 1995). Tree trunks were banded by wrapping them with duct tape and then applying Tree Tanglefoot to the center of the tape. Small gaps between the tape and the tree were filled with Tree Tanglefoot to prevent larvae from passing beneath the barrier (Thorpe et al. 1993). Thorpe et al. (1993) found that late-instar population densities in the oak canopies of banded plots were significantly lower than those of unbanded plots. Thorpe et al. (1993) also found that defoliation rates and the ratio of post-treatment to pretreatment egg mass density was not significantly affected by banding. They concluded that the effects of the sticky barriers on defoliation were inconsistent and that these barriers should not be relied on to protect oak foliage from gypsy moths. Despite being widely used for many decades, there exists little published information on the actual efficacy of tanglefoot bands in capturing cankerworm adults in urban forests.

Envirometrics Systems, Inc. (London, Ontario) markets an alternate version of a sticky band to prevent adult females of A. pometaria and P. vernata from reaching the canopy to lay eggs. The Bug Barrier Tree Band ${ }^{\mathrm{TM}}$ consists of a layer of synthetic foam placed around the trunk over which a plastic shield is placed, which rests several centimeters away from the bark. The underside of this plastic shield is coated with an adhesive film on which insects become trapped. The product is also meant to be effective against gypsy moth, forest tent caterpillar, and ants (Envirometrics Systems 2005).

Envirometrics Systems has designed the band to be unaffected by falling debris such as leaves, twigs, and bark and to require little maintenance (Envirometrics Systems 2002). The company notes that the product is easily installed and removed, without the mess and stickiness encountered when using traditional sticky bands (Envirometrics Systems 2005).

The purpose of this study was to compare the effectiveness of tanglefoot bands and the Bug Barrier Tree Band in preventing the upward movement of female cankerworms on the trunk and to examine cankerworm preference for tree species. The efficacy of the bands was determined by measuring the defoliation caused by cankerworm larvae, the number of larvae per branch sample, and by observing the number of female moths that crossed over the test bands.

\section{MATERIALS AND METHODS Experiment 1}

Experiment 1 (fall 2002) was replicated at two sites, St. John's Cemetery and along Lyndale Drive in Winnipeg, Manitoba ( $49^{\circ} 53^{\prime} \mathrm{N}, 97^{\circ} 09^{\prime} \mathrm{W}$ ). Sites were approximately 5 $\mathrm{km}(3 \mathrm{mi})$ apart and were chosen because they had a history of cankerworm defoliation. Host trees included green ash (Fraxinus pennsylvanica var. subintegerrima (Vahl) Fern.), American elm (Ulmus americana L.), and Siberian elm (Ulmus pumila L. ). St. John's Cemetery is surrounded by a large residential community and bordered by the Red River on the eastern edge approximately $200 \mathrm{~m}$ (219 yd) away. Lyndale Drive is a park bordered on the southwest side by the Red River and northeast side by a residential community.

All treatment trees were in close proximity to each other but were far enough apart to prevent larvae from moving between trees via silken threads. Treatment trees were estimated to be at least $4 \mathrm{~m}(13 \mathrm{ft})$ in height and were identified as being healthy at the beginning of the experiment (no infections of Dutch elm disease were apparent in elm trees). Diameter at breast height (dbh) was recorded for each tree using a standard dbh tape. Two treatments were established at each site. Treatment 1 consisted of a Bug Barrier Tree Band placed approximately $1.3 \mathrm{~m}$ (4.3 ft) high on the trunk (Figure 1), and treatment 2 consisted of a tanglefoot band placed at $1.3 \mathrm{~m}(4.3 \mathrm{ft})$ high on the trunk (Figure 2). Treatments were randomly assigned and replicated eight times at Lyndale Drive and five times at St. John's Cemetery. Bands were placed on trees prior to adult emergence in September 2002 and removed after the first significant snowfall in November 2002. They were wrapped in plastic bags for transport and the number of A. pometaria adults captured was determined in the laboratory. 


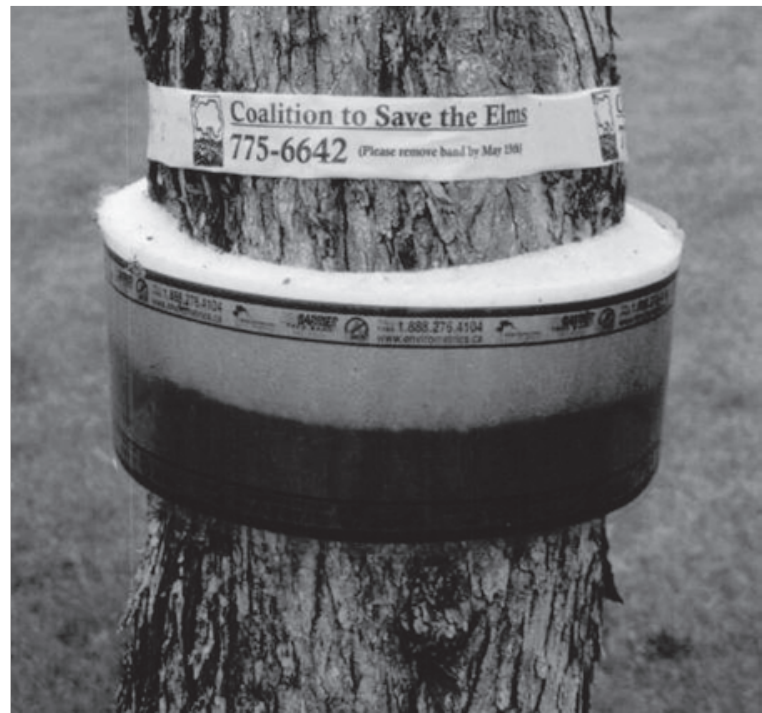

Figure 1. Experiment 1 (fall 2002), treatment 1: a single Bug Barrier Tree Band ${ }^{\mathrm{TM}}$ at $1.3 \mathrm{~m}(4.3 \mathrm{ft})$ on trunk.

\section{Experiment 2}

Experiment 2 (spring 2003) was replicated at the two sites noted previously, using different trees. Three treatments and a control were established at each site. In treatment 1, a Bug Barrier Tree Band was placed at breast height with a tanglefoot band placed $30 \mathrm{~cm}$ (12 in) above it (Figure 3). Treatment 2 consisted of a single Bug Barrier Tree Band. In treatment 3, a tanglefoot band was placed at breast height with a second tanglefoot band $30 \mathrm{~cm}$ (12 in) above it (Figure 4). Control trees were established for the defoliation component of the study and did not receive a banding treatment. The distribution and presence of host trees dictated the number of replications and number of controls at each site. All treatments were replicated eight times at Lyndale Drive $(n=32)$, while treatment 1 was replicated three times, and treatments 2, 3 and the controls were replicated five times at St. John's Cemetery $(n=18)$.

Height and dbh were recorded for each treatment tree at each site. Host trees included green ash, Siberian elm, and American elm. Height was calculated using a SUUNTO PM$5 / 360$ PC clinometer from a distance of $20 \mathrm{~m}$ (22 yd). The height at eye level was estimated to be approximately $1.5 \mathrm{~m}$ $(4.9 \mathrm{ft})$. Tree height was measured to the nearest meter using the rounding method described by Husch et al. (2003).

Leaf defoliation was measured by obtaining leaf samples from each host tree. A pole pruner was used to sample leaves from the middle one-third of the canopy. Two $30 \mathrm{~cm}$ (12 in) branch samples were taken from each tree at opposite compass points (if accessible). Defoliation for each individual leaf (percentage of leaf tissue missing) on the twig

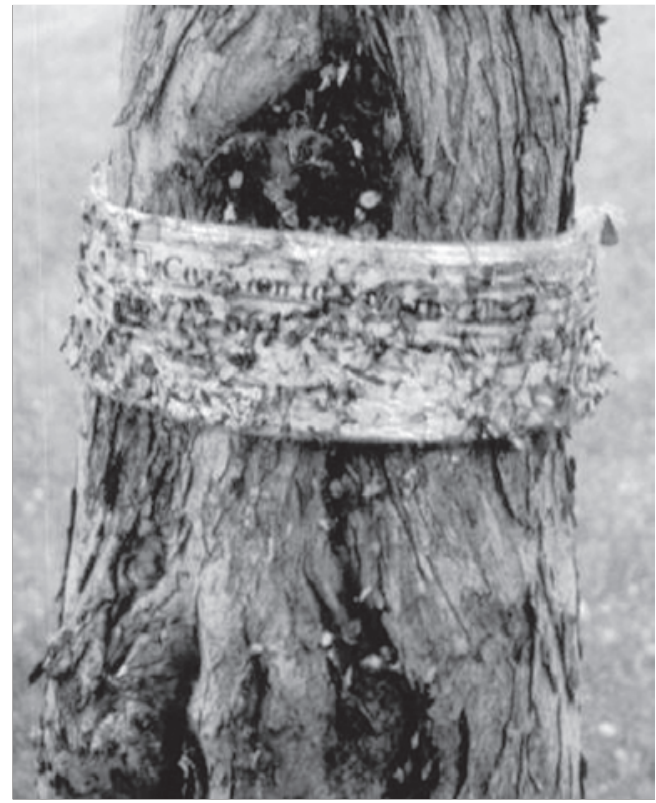

Figure 2. Experiment 1 (fall 2002), treatment 2: a single tanglefoot band at $1.3 \mathrm{~m}$ (4.3 ft) on trunk.

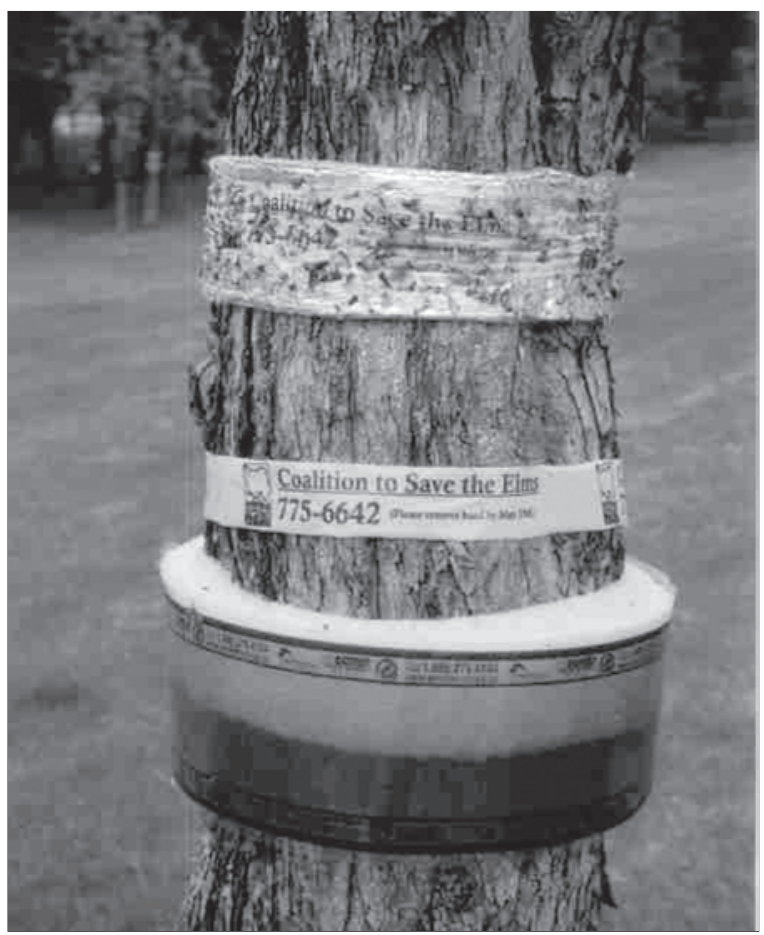

Figure 3. Experiment 2 (spring 2003), treatment 1: a Bug Barrier Tree Band ${ }^{\mathrm{TM}}$ at $1.3 \mathrm{~m}$ (4.3 ft) and a tanglefoot band placed $30 \mathrm{~cm}$ (12 in) above it.

was estimated to the nearest $5 \%$. These estimates were recorded, and the average defoliation per twig sample was calculated. The number of larvae found per branch sample 


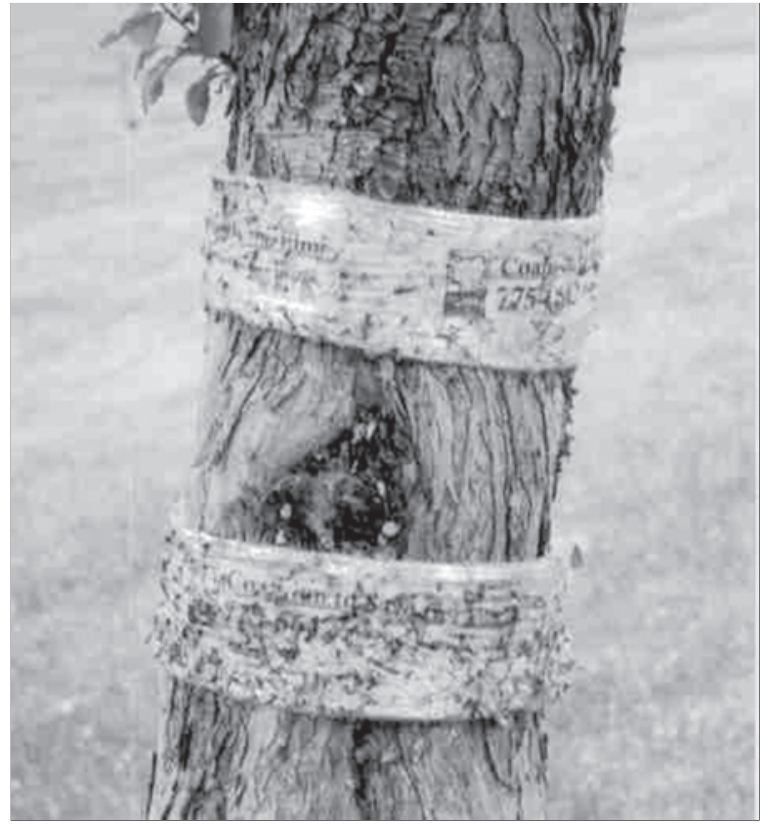

Figure 4. Experiment 2 (spring 2003), treatment 2: a tanglefoot band at $1.3 \mathrm{~m}(4.3 \mathrm{ft})$ and a second tanglefoot band placed $30 \mathrm{~cm}(12 \mathrm{in})$ above it.

was recorded during the defoliation estimates (no distinction was made between $A$. pometaria and A. vernata larvae). Defoliation estimates and larval counts were made every 5 days between 12 May and 14 June 2003.

The Bug Barrier Tree Bands and tanglefoot bands were installed prior to 12 May, which was the first day larvae were found, and the study lasted until 14 June 2003. All bands were stored in separate bags for transport and storage. Tanglefoot bands were first wrapped in Saran ${ }^{\mathrm{TM}}$ plastic wrap and then removed from the tree to reduce the mess and for ease of transport. After collection, the bands were taken to the laboratory to assess the number of $A$. vernata adults captured.

\section{Experiment 3}

Experiment 3 (fall 2003) was conducted at St. John's Cemetery using trees different from those used in the fall 2002 and spring 2003 experiments. New bands were installed at the site on 15 September, prior to the emergence of $A$. pometaria adults. There was no control because defoliation measurements could not be made. Treatment 1 consisted of a Bug Barrier Tree Band placed at breast height with a tanglefoot band placed $30 \mathrm{~cm}$ (12 in) above it $(n=7)$, and treatment 2 consisted of a tanglefoot band placed at breast height with a second tanglefoot band placed $30 \mathrm{~cm}$ (12 in) above it $(n=7)$. Host tree species included green ash and American elm. The height and dbh of each tree were recorded using the same method as in the spring 2003 study. The study concluded on 27 October after significant snowfall. Bands were collected in the same manner as the previous experiments.

\section{Statistical Analysis}

Prior to analysis, data for all variables were log transformed (except the average number of larvae per branch) to meet the assumptions of a normal distribution (Zar 1996). The relationship between adult moths caught and tree height and diameter was explored to ensure that band capture results were not influenced by these variables. Preliminary analysis with Pearson product-moment correlation showed no significant relationship $(P>0.05)$ between the capture of males and females with tree diameter or tree height in experiments 1 and 2. In experiment 3, there was a significant relationship between males and tree diameter $(r=$ $0.687, P=0.007)$ and tree height $(r=0.586, P=0.028)$, and these data were removed from the experiment. There was no correlation between number of females captured and tree diameter or tree height $(P>0.05)$ in experiment 3. Data from the two sites of experiment 1 were pooled for analysis due to the small sample size at St. John's Cemetery.

Analysis of variance (ANOVA) was used to compare defoliation rates and number of larvae per branch among the four treatments (SPSS 2000). ANOVA was also used to compare the number of moths captured for treatments in experiments 1 and 3. In experiment 2, ANOVA was used to test for differences between treatments and tree species. Tukey's HSD post hoc test was used to test differences among treatments when ANOVA results were significant $(P$ $<0.05)$. In experiments 2 and 3, capture rates among treatments were also compared using the proportion of females that crossed over the bottom bands and were captured by the top band. The proportion of females crossing the bands in each treatment were recorded as a percentage and was arcsin transformed to meet the requirements of a normal distribution. ANOVA was used to compare the capture rates between top and bottom bands for each treatment.

\section{RESULTS \\ Experiment 1}

In fall 2002, there was no significant difference in adult capture for A. pometaria among tree species (Table 1). There was no significant difference in the capture of $A$. pometaria females between the two band types; however, tanglefoot bands caught significantly more males $\left(F_{1,24}=3.49, P=\right.$ 0.002) than the Bug Barrier Tree Band (Table 2).

\section{Experiment 2}

In the spring 2003 experiment, there was no significant difference in percentage leaf defoliation or average number of larvae of A. pometaria and P. vernata per sample among 
Table 1. Mean number of males and females captured per tree species at Lyndale Drive and St. John's Cemetery.

\begin{tabular}{|c|c|c|c|c|c|}
\hline Experiment no. & $\begin{array}{l}\text { Cankerworm } \\
\text { species }\end{array}$ & Tree species & $n$ & $\begin{array}{l}\text { Mean females } \\
\pm \text { SEM }\end{array}$ & $\begin{array}{l}\text { Mean males } \\
\pm \text { SEM }\end{array}$ \\
\hline 1 (sites pooled) & A. pometaria & $\begin{array}{l}\text { American elm } \\
\text { Siberian elm } \\
\text { Green ash } \\
F_{2,23} \\
P\end{array}$ & $\begin{array}{r}13 \\
5 \\
8\end{array}$ & $\begin{array}{r}129.62 \pm 33.19 \\
49.40 \pm 17.08 \\
77.12 \pm 18.99 \\
0.618 \\
0.548\end{array}$ & $\begin{array}{r}116.31 \pm 33.28 \\
57.80 \pm 20.00 \\
52.12 \pm 23.57 \\
1.078 \\
0.357\end{array}$ \\
\hline 2 (Lyndale) & P. vernata & $\begin{array}{l}\text { American elm } \\
\text { Siberian elm } \\
\text { Green ash } \\
F_{2,13} \\
P\end{array}$ & $\begin{array}{l}7 \\
5 \\
4\end{array}$ & $\begin{array}{r}26.86 \pm 5.93 b^{*} \\
66.20 \pm 17.58 \mathrm{~b} \\
4.25 \pm 1.12 \mathrm{a} \\
17.921 \\
<0.001\end{array}$ & $\begin{array}{r}147.14 \pm 43.43 b \\
289.00 \pm 72.70 b \\
13.25 \pm 3.45 a \\
28.741 \\
<0.001\end{array}$ \\
\hline 2 (St. John's) & P. vernata & $\begin{array}{l}\text { American elm } \\
\text { Green ash } \\
F_{1,6} \\
P\end{array}$ & $\begin{array}{l}5 \\
3\end{array}$ & $\begin{array}{r}45.20 \pm 12.50 \\
27.33 \pm 10.27 \\
0.811 \\
0.402\end{array}$ & $\begin{array}{r}128.40 \pm 40.18 \\
73.00 \pm 11.15 \\
1.025 \\
0.350\end{array}$ \\
\hline 3 (St. John's) & A. pometaria & $\begin{array}{l}\text { American elm } \\
\text { Green ash } \\
F_{1,12} \\
P\end{array}$ & $\begin{array}{l}8 \\
6\end{array}$ & $\begin{array}{r}12.50 \pm 2.64 \\
23.50 \pm 8.92 \\
2.117 \\
0.171\end{array}$ & $\begin{array}{r}208.62 \pm 39.92 \\
101.67 \pm 26.30 \\
4.258 \\
0.061\end{array}$ \\
\hline
\end{tabular}

* Means within each column followed by different letters are significantly different (Tukey's HSD, ANOVA $P<0.05$ ).

the four treatments at Lyndale Drive or St. John's Cemetery (Table 3). There was no significant difference in P. vernata adult capture among tree species at St. John's Cemetery, but significantly fewer males $\left(F_{2,13}=28.74, P<0.001\right)$ and females were found on green ash $\left(F_{2,13}\right.$ $=17.92, P<0.001)$ at Lyndale Drive (Table 1). At Lyndale Drive in spring 2003, there was no significant difference between the two treatments in the capture of $P$. vernata females between the band types, and no differences were found in the proportion of females that crossed over the bottom barrier to be caught by the top band (Table 4). At St. John's Cemetery, significantly fewer $P$. vernata females were captured by the bottom Bug Barrier Tree Band in treatment 1 than the bottom tanglefoot band in treatment $2\left(F_{1,6}=25.098, P=\right.$ 0.002 ), and significantly fewer females crossed over the tanglefoot band than the Bug Barrier Tree Band $\left(F_{1,6}=\right.$ 25.100, $P=0.002$ ) (Table 4).
Table 2. Comparison of mean A. pometaria males and females captured per treatment on Lyndale Drive and St. John's Cemetery in experiment 1.

\begin{tabular}{|c|c|c|c|c|}
\hline Treatment & Band type & $n$ & $\begin{array}{l}\text { Mean females } \\
\pm \text { SEM }\end{array}$ & $\begin{array}{l}\text { Mean males } \\
\pm \text { SEM }\end{array}$ \\
\hline 1 & Bug Barrier Tree BandTM & 13 & $106.54 \pm 31.30$ & $34.69 \pm 11.18$ \\
\hline \multirow[t]{3}{*}{2} & tanglefoot band & 13 & $89.54 \pm 21.39$ & $135.92 \pm 31.10$ \\
\hline & $F_{1,24}$ & & $0.200^{*}$ & 3.494 \\
\hline & $P^{1,24}$ & & 0.843 & 0.002 \\
\hline
\end{tabular}

*ANOVA, $\alpha=0.05$

Table 3. Mean percentage of defoliation and mean number of larvae of $A$. pometaria and $P$. vernata per branch sample per treatment for Lyndale Drive and St. John's Cemetery in experiment 2.

\begin{tabular}{llcc}
\hline Site/treatment & $n$ & $\begin{array}{c}\text { Mean percentage of } \\
\text { defoliation } \pm \text { SEM }\end{array}$ & $\begin{array}{c}\text { Mean number of } \\
\text { larvae/branch } \pm \text { SEM }\end{array}$ \\
\hline Lyndale & & & \\
1: Bug Barrier ${ }^{\mathrm{TM}}+$ tanglefoot & 8 & $7.88 \pm 1.98$ & $1.73 \pm 0.45$ \\
2: Bug Barrier & 8 & $8.07 \pm 3.89$ & $1.56 \pm 0.58$ \\
3: tanglefoot + tanglefoot & 8 & $8.27 \pm 2.11$ & $1.60 \pm 0.45$ \\
4: control & 8 & $8.33 \pm 1.81$ & $1.75 \pm 0.70$ \\
& $F_{3,28}$ & $0.156^{*}$ & 0.028 \\
& $P$ & 0.925 & 0.994 \\
St. John's & & & $2.06 \pm 1.31$ \\
1: Bugg Barrier + tanglefoot & 3 & $14.04 \pm 8.11$ & $4.30 \pm 1.53$ \\
2: Bug Barrier & 5 & $10.37 \pm 4.64$ & $3.67 \pm 1.46$ \\
3: tanglefoot + tanglefoot & 5 & $7.87 \pm 3.52$ & $4.33 \pm 1.54$ \\
4: control & 5 & $10.65 \pm 4.76$ & 0.376 \\
& $F_{3,28}$ & 0.081 & 0.772 \\
\hline
\end{tabular}

*ANOVA, $\alpha=0.05$ 
Table 4. Comparison of mean female capture rates for the Bug Barrier Tree Band ${ }^{\mathrm{TM}}$ and tanglefoot bands for Lyndale Drive and St. John's Cemetery for experiment 2 (P. vernata) and experiment 3 (A. pometaria).

\begin{tabular}{|c|c|c|c|c|c|}
\hline Experiment no. & Site/treatment & $n$ & $\begin{array}{l}\text { Total mean } \\
\text { females caught per } \\
\text { treatment } \pm \text { SEM }\end{array}$ & $\begin{array}{l}\text { Mean percentage } \\
\text { caught on bottom } \\
\text { band } \pm \text { SEM }\end{array}$ & $\begin{array}{l}\text { Mean percentage } \\
\text { caught on top } \\
\text { band } \pm \text { SEM }\end{array}$ \\
\hline \multirow[t]{10}{*}{2} & Lyndale & & & & \\
\hline & 1: Bug Barrier ${ }^{\mathrm{TM}}+$ tanglefoot & 8 & $26.75 \pm 12.83$ & $70.69 \pm 10.91$ & $29.31 \pm 10.91$ \\
\hline & 2: tanglefoot + tanglefoot & 8 & $40.25 \pm 11.02$ & $91.94 \pm 3.76$ & $8.06 \pm 3.76$ \\
\hline & $F_{114}$ & & $0.637^{*}$ & 2.649 & 2.711 \\
\hline & $P^{1,14}$ & & 0.438 & 0.126 & 0.122 \\
\hline & St. John's & & & & \\
\hline & 1: Bug Barrier + tanglefoot & 3 & $17.33 \pm 7.42$ & $21.53 \pm 10.78$ & $78.47 \pm 10.78$ \\
\hline & 2: tanglefoot + tanglefoot & 5 & $51.20 \pm 9.69$ & $84.57 \pm 2.35$ & $5.43 \pm 2.35$ \\
\hline & $F_{1,6}$ & & 5.845 & 25.098 & 25.100 \\
\hline & $P$ & & 0.052 & 0.002 & 0.002 \\
\hline \multirow[t]{5}{*}{3} & St. John's & & & & \\
\hline & 1: Bug Barrier + tanglefoot & 7 & $20.14 \pm 8.12$ & $74.72 \pm 9.51$ & $25.28 \pm 9.51$ \\
\hline & 2: tanglefoot + tanglefoot & 7 & $18.57 \pm 6.73$ & $81.46 \pm 5.26$ & $18.54 \pm 5.26$ \\
\hline & $F_{1,12}$ & & 0.022 & 0.243 & 0.243 \\
\hline & $P^{1,12}$ & & 0.884 & 0.631 & 0.631 \\
\hline
\end{tabular}

*ANOVA, $\alpha=0.05$.

\section{Experiment 3}

No significant difference was found in adult female $A$. pometaria capture rates among tree species or between band types at St. John's Cemetery in fall 2003 (Tables 1 and 4). There were no significant differences in the proportion of females that crossed the bottom barriers (Table 4).

\section{DISCUSSION}

Mean percentage of leaf defoliation and mean number of larvae per branch sample did not significantly differ between trees with or without bands in experiment 2. It should be noted that the bands were installed in early May, so $A$. pometaria females may have already deposited eggs in the canopy of host trees in the previous fall. Paleacrita vernata does not lay eggs until spring; therefore, the bands in the spring 2003 experiment prevented only P. vernata females from reaching the canopy. Thus, host trees may have also experienced defoliation by A. pometaria. Since there was no difference in the number of larvae between the control and the treatment trees, larval populations of both species were probably too low to exhibit significant defoliation.

There was no significant difference in the number of females of $A$. pometaria captured among tree species in either of the fall experiments, which suggests that adults were equally attracted to all tree species. At Lyndale Drive in experiment 2 , however, significantly fewer males and females were found on green ash compared to American elm and Siberian elm, which could indicate that $P$. vernata may prefer elm over ash.
In experiment 1 , there were significantly fewer males captured by the Bug Barrier Tree Band compared to the tanglefoot bands. This may be due the design of the Bug Barrier Tree Band-males must fly beneath the band and then away from the trunk to be captured (Figure 5).

At Lyndale Drive in experiment 2 and at St. John's Cemetery in experiment 3, there were no significant differences between the top tanglefoot band in treatment 1 and the top tanglefoot in treatment 2 in the numbers of

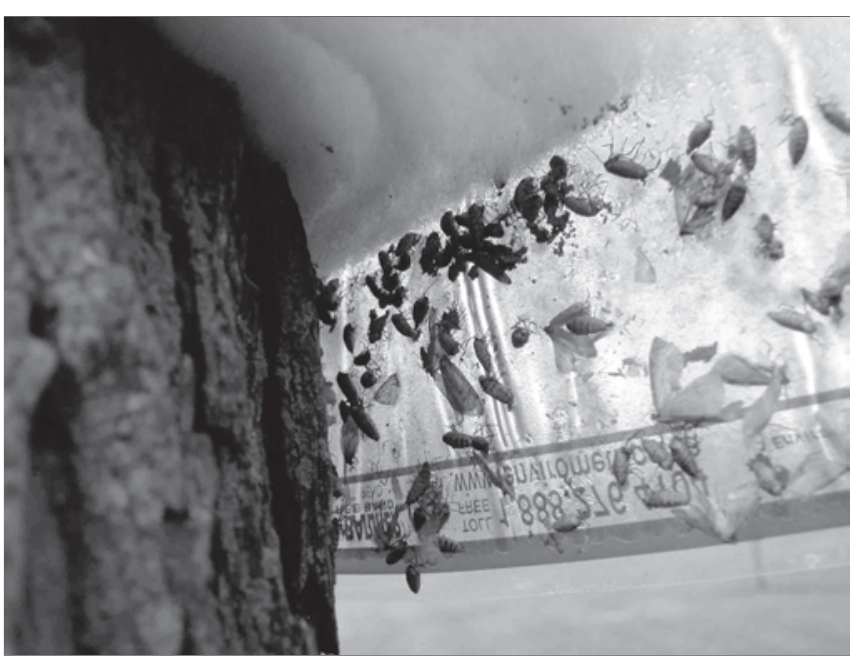

Figure 5: Underside of the Bug Barrier Tree Band ${ }^{\mathrm{TM}}$ showing captured male and female moths. The adhesive surface of the band rests several centimeters away from the bark of the tree. 
females caught, which suggests that the Bug Barrier Tree Band was equally effective as the tanglefoot bands. At St. John's Cemetery in experiment 2, the Bug Barrier Tree Band was not as effective as tanglefoot bands in capturing adult females: the bottom tanglefoot bands caught more females than the Bug Barrier Tree Band, and significantly more females crossed the Bug Barrier Tree Band than the tanglefoot bands.

The female capture rates from experiments 2 and 3 showed that at least $25 \%$ of female moths cross the Bug Barrier Tree Band. Occasionally, females were found within the foam barrier beneath the band, which indicated that females were capable of crawling through the synthetic foam on the Bug Barrier Tree Band and were able to crawl under the barrier through bark crevices. Approximately 5\% to 20\% of females crossed the tanglefoot bands. It should be noted, however, that the tanglefoot bands were consistently overcrowded with males that females may have used as a bridge to cross the barrier. Tanglefoot bands were not completely effective at capturing females and more than one tanglefoot band may be required to prevent the majority of female cankerworms from reaching the canopy when the population density is high. The effectiveness of tanglefoot bands should be investigated over a range of cankerworm densities, because one tanglefoot band has traditionally been considered sufficient for cankerworm control. Perhaps the width of the tanglefoot bands could also be examined to increase their effectiveness.

The Bug Barrier Tree Band was much easier to install and remove than the tanglefoot bands and required less cleanup afterwards. When collecting the tanglefoot bands at the end of the summer, it was noted that considerable moisture was trapped on the bark beneath the bands. This attracted other insects (e.g., Formicidae, Hemiptera, and Homoptera) and encouraged the growth of fungi on the trunk. There was less moisture, and no fungi were present beneath the Bug Barrier Tree Band.

Several small, dead birds were found under the Bug Barrier Tree Band during the course of the study, and they may have been trapped while feeding on the insects caught under the band. There were no observations of birds attempting to feed on insects on the tanglefoot bands. Minor damage was caused to some of the Bug Barrier Tree Bands by squirrels. Presumably, squirrels tried to climb over the band, which resulted in the plastic shield being compressed against the trunk. It was observed that larvae were then able to crawl over the sticky barrier. The band had to be forcibly pulled away from the bark in order to rectify the problem.

\section{LITERATURE CITED}

Ascerno, M.E., and J. Hahn. 2003. Spring and Fall

Cankerworms. The College of Agricultural, Food and

Environmental Sciences, University of Minnesota

Extension Service. www.extension.umn.edu/distribution/ horticulture/DG0876.html (accessed 11/23/05).
Baker, W.L. 1972. Eastern Forest Insects. Miscellaneous publication no. 1175. U.S. Department of Agriculture, Forest Service. Washington, DC. 642 pp.

Envirometrics Systems, Inc. 2002. Envirometrics Systems, Inc. Web site. www.envirometrics.ca (accessed 11/23/05).

Hiratsuka, Y., Langor, D.W., and P.E. Crane. 1995. A field guide to forest insects and diseases of the Prairie provinces. Special report 3. Natural Resources Canada, Canadian Forest Service, Northwest Region, Northern Forestry Centre, Edmonton, AB. 297 pp.

Husch, B., Beers, T.W., and J.A. Kershaw Jr. 2003. Forest Mensuration (4th ed.). John Wiley \& Sons, Hoboken, NJ. $443 \mathrm{pp}$.

Ives, W.G.H., and H.R. Wong. 1988. Tree and Shrub Insects of the Prairie Provinces. Northern Forestry Centre, Canadian Forest Service, Edmonton, AB. 327 pp.

Martineau, R. 1984. Insects Harmful to Forest Trees. Multiscience Publications, Montréal, QC. 261 pp.

McGuffin, W.C. 1977. Guide to the Geometridae of Canada (Lepidoptera). II. Subfamily Ennominae. 2. The Entomological Society of Canada, Ottawa, ON. 191 pp.

Otvos, I.S., and R.S. Hunt.1986. Evaluation of three types of barriers to trap winter moth Lepidoptera: Geometridae) adults. Journal of the Entomological Society of British Columbia 83:27-30.

Schneider, J.C. 1980. The role of parthenogenesis and female aptery in microgeographic, ecological adaption in the fall cankerworm, Alsophila pometaria Harris (Lepidoptera: Geometridae). Ecology 61(5):1082-1090. SPSS, Inc. 2000. SPSS 10.1.0 for Windows. SPSS, Chicago, IL. Tanglefoot Company, Inc. 2002. After All These Years, Tanglefoot Is Still "Sticking Around." The Tanglefoot Company, Inc., Grand Rapids, MI. www.tanglefoot.com/ history.htm (accessed 11/23/05).

Thorpe, K.W., R.E. Webb, R.L. Ridgway, L. Venables, and K.M. Tatman. 1993. Sticky barrier bands affect density of gypsy moth (Lepidoptera: Lymantriidae) and damage in oak canopies. Journal of Economic Entomology 86(5):1497-1501.

Zar, J.H. 1996. Biostatistical Analysis (3rd ed.) Prentice Hall, Upper Saddle River, NJ. 662 pp.

Acknowledgments. The authors thank Raymond Normandeau for assistance with the field work; Randy Gadawski and Martha Barwinsky, City of Winnipeg, Forestry Branch, for assistance with experimental design and site location; and Richard Staniforth and Andy Park, Department of Biology, University of Winnipeg, for manuscript review. Funding for this project was provided by Envirometrics Systems, Inc., Manitoba Conservation, the University of Winnipeg Department of Biology, and the University of Winnipeg Centre for Forest Interdisciplinary Research. 
Kerienne R. La France

Centre for Forest Interdisciplinary Research

515 Portage Avenue

Winnipeg, $M B$

R3B 2E9

Canada

Dr. A. Richard Westwood (corresponding author)

Department of Biology

University of Winnipeg

515 Portage Avenue

Winnipeg, $M B$

R3B 2E9

Canada

Résumé. L'arpenteuse d'automne (Alsophila pometaria L.) et l'arpenteuse printanière (Paleacrita vernata Peck) sont largement distribuées en Amérique du Nord. Les larves se nourrissent sur les feuilles de plusieurs espèces d'arbres de rues en milieu urbain et une défoliation répétée peut causer une réduction de croissance et ainsi contribuer à la mortalité des arbres. Cette étude examine l'efficacité des bandes collantes de Tanglefoot ${ }^{\mathrm{TM}}$ sur les arbres ainsi que des bandes de Bug Barrier Tree Band ${ }^{\mathrm{TM}}$ pour prévenir l'ascension le long du tronc des femelles d'arpenteuse, et ce en comparant le taux de capture des insectes adultes. Il n'y avait aucune différence significative quant au nombre de A. pometaria capturés entre les différentes espèces d'arbres tandis que $P$. vernata démontrait une préférence pour l'orme par rapport au frêne. Jusqu'à $25 \%$ des femelles d'arpenteuse traversaient les bandes de Bug Barrier Tree Band et $20 \%$ dans le cas de celles de Tanglefoot lors de trois expériences menées en 2002 et 2003. Il n'y avait pas de différence significative entre les deux types de bandes quant à la proportion de femelles traversant ces bandes. Les populations de larves n'étaient pas suffisamment importantes pour déterminer les effets de ces bandes sur la diminution de la défoliation chez les arbres. Le Bug Barrier Tree Band était plus facile à installer et à enlever que le Tanglefoot, et exigeait moins de nettoyage par la suite.

Zusammenfassung. Der Herbst-Krebswurm (Alsophila pometaria L.) und der Frühlingskrebswurm (Paleacrita vernata
Peck) sind in Nordamerika weit verbreitet. Die Larve frisst die Blätter von verschiedenen urbanen Bäumen und wiederholte Defoliation kann einen Wachstumsrückgang verursachen oder auch zum Absterben beitragen. Diese Studie untersucht die Effektivität von Tanglefoot ${ }^{\mathrm{TM}}$ Baumbändern und Bug Barrier ${ }^{\mathrm{TM}}$ Baumbändern bei der Bekämpfung von Larvenmigration durch den Vergleich mit gefangenen weiblichen Motten. Es gab keine besonderen Unterschiede in der Anzahl der Erwachsenen der einen Art A. pometaria oder anderen Art, während P. vernata eine Vorliebe für Kastanie und Kastanie zeigte. Bis zu 25 \% der weiblichen Motten überschritten das Bug Barrier Tree Band und bis zu 20 \& der weiblichen Motten zeigten eine Vorliebe für Ulme gegenüber Esche. Bis zu 20 \% der weiblichen Motten überschritten das TanglefootBaumband in insgesamt 3 Experimenten in 2002 und 2003. Es gab keine deutlichen Unterschiede zwischen den beiden Bändern im Vergleich mit den überquerenden weiblichen Motten. Die Larvenpopulationen waren nicht groß genug, um den Einfluss der Bänder auf die Entlaubung zu bestimmen. Das Bug BarrierTM Baum Band war leichter einzubauen und zu entfernen als das Tanglefoot-Band und erforderte wesentlich weniger Aufräumen hinterher.

Resumen. Los insectos defoliadores Alsophila pometaria L. y Paleacrita vernata Peck están ampliamente distribuidos a lo largo de América del Norte. La larva se alimenta de las hojas de varias especies de árboles urbanos y una defoliación severa repetida puede causar una reducción del crecimiento y puede contribuir a la muerte del árbol. Este estudio examinó la efectividad de las bandas de Tanglefoot ${ }^{\mathrm{TM}} \mathrm{y}$ de Bug Barrier Tree Band ${ }^{\mathrm{TM}}$ para prevenir el movimiento ascendente de las larvas femeninos por el tronco, comparándolo con la captura de polillas adultas. No se presentaron diferencias significativas en el número de A. pometaria adultos capturados entre tres especies, mientras que P. vernata mostró una preferencia por el olmo sobre el fresno. Más del 25\% de polillas hembra cruzaron la Bug Barrier Tree Band y más de 20\% de hembras cruzaron las bandas de Tanglefoot en tres experimentos en 2002 y 2003. No hubo una diferencia significativa entre los dos tipos de barrera con respecto a la proporción de hembras cruzando las bandas. Las poblaciones de larvas no fueron suficientemente grandes para determinar el efecto de las bandas para reducir la defoliación del árbol. Bug Barrier Tree Band fue más fácil de instalar y de remover que Tanglefoot, y requirieron después considerablemente menos limpieza. 